\title{
Artikel
}

\section{Verantwoordelijkheid voor mensenrechtenschendingen WK voetbal} Qatar

\author{
Daniela Heerdt*
}

\section{Inleiding}

In februari 2021 publiceerde The Guardian een onderzoek waarin gesteld werd dat er op bouwplaatsen in Qatar, die meestal verbonden zijn aan het WK voetbal dat in 2022 in Qatar gehouden wordt, in de afgelopen tien jaar ca. 6500 arbeidsmigranten zijn overleden. ${ }^{1}$ Dit bericht heeft geleid tot een grote heropleving van bewustzijn van de situatie van arbeidsmigranten in Qatar, dat groeiende is sinds het evenement in 2010 aan Qatar werd gegund. ${ }^{2}$ Vele onderzoeken vermeldden gevaarlijke en onmenselijke arbeidsomstandigheden, waarbij arbeiders worden blootgesteld aan hitte tot vijftig graden Celsius, vaak zonder pauzes en zonder toegang tot drinkwater. Meer dan de helft van alle arbeidsmigranten woonde en woont nog steeds in werkkampen

* Dr. D.M. (Daniela) Heerdt is researcher aan de Universiteit van Tilburg en onafhankelijk consultant op het gebied van sport- en mensenrechten.

1. The Guardian (2021), Revealed: 6,500 migrant workers have died in Qatar since World Cup awarded, www.theguardian.com/globaldevelopment/2021/feb/23/revealed-migrant-worker-deaths-qatar-fifaworld-cup-2022, geraadpleegd op 21 mei 2021.

2. Internationaler Gewerkschaftsbund (2013), Qatar 2022 World Cup Risks 4000 Lives, Warns International Trade Union Confederation, www.ituc-csi.org/qatar-2022-world-cup-risks-4000?lang=de; Human Rights Watch, geraadpleegd op 3 februari 2017; Qatar: Take Urgent Action to Protect Construction Workers; Owen Gibson \& Pete Pattisson, Death Toll among Qatar's 2022 World Cup Workers Revealed, The Guardian 2014, www.theguardian.com/world/2014/dec/23/qatarnepal-workers-world-cup-2022-death-toll-doha, geraadpleegd op 16 januari 2018. met erbarmelijke huisvesting en armzalige sanitaire voorzieningen. ${ }^{3}$ De toepassing van de 'Sponsorwet' van Qatar, beter bekend als het kafala-systeem, dat haar wortels heeft in een bedoeienentraditie, die oorspronkelijk bedoeld was om de behandeling en bescherming van buitenlandse gasten te regelen, ${ }^{4}$ heeft het risico op uitbuiting van arbeidsmigranten vergroot, aangezien arbeidsmigranten afhankelijk zijn van sponsors, als werknemers het land niet mogen verlaten, en ook niet van werkgever mogen veranderen zonder dat hun werkgever hen daarvoor een vergunning geeft. Ook nu het kafala-systeem inmiddels officieel is afgeschaft, blijft de overgrote meerderheid van de arbeidsmigranten in Qatar onderworpen aan wat 'dwangarbeid' en 'moderne slavernij' wordt genoemd. ${ }^{5}$ De voortdurende COVID-19-pandemie maakt de rechtenschendingen die arbeidsmigranten ondergaan nog groter en ernstiger. Een recent onderzoek door Human Rights Watch (HRW) bracht aan het licht dat de soorten misbruik niet nieuw zijn, maar dat de verspreiding en de schaal waarop deze plaatsvinden door de pandemie worden ver-

3. Leana Hosea, Inside Qatar's Squalid Labour Camps, BBC News 7 March 2014, www.bbc.com/news/world-middle-east-26482775, geraadpleegd op 8 maart 2018.

4. Azfar Khan \& Hélène Harroff-Tavel, Reforming the Kafala: Challenges and Opportunities in Moving Forward, Asian and Pacific Migration Journal 2011, 20, p. 293, 294.

5. United Nations Committee on the Elimination of Racial Discrimination, Consideration of reports submitted by states parties under article 9 of the Convention - Concluding observations of the Committee on the Elimination of Racial Discrimination, 13 April 2012, UN Doc CERD/C/QAT/CO/13-16, par. 15; United Nations General Assembly, Report of the Special Rapporteur on the human rights of migrants, François Crépeau, 23 April 2014, UN Doc A/HRC/26/35/Add.1, par. 25-32. 
sterkt. ${ }^{6}$ Dit betreft zowel de arbeids- en woonomstandigheden als de mogelijkheden tot verhaal. Amnesty International meldde dat arbeidsmigranten die gevangen zitten in werkkampen in Qatar in het bijzonder risico lopen op blootstelling aan het virus vanwege hun leefsituatie en hun gebrek aan toegang tot gezondheidszorg. ${ }^{7}$

Terwijl de bewijzen zich opstapelen, ontbreekt het aan praktische oplossingen om deze mensenrechtenschendingen aan te pakken, ondanks enkele initiatieven van het Supreme Committee for Delivery and Legacy ('SC'), het Organisatiecomité van het WK en de arbeidsrechtelijke hervormingen die de regering van Qatar heeft geintroduceerd. Er zijn nieuwe accommodaties gebouwd voor bouwvakkers die werken op officiële bouwplaatsen van het WK. ${ }^{8}$ Het SC heeft ook het Universal Reimbursement Scheme aangenomen dat wervingskosten terugbetaalt, ongeacht of arbeiders bewijs kunnen overleggen. De wetgever van Qatar heeft wijzigingen aangenomen op Qatars arbeidswet, Wet nr. 14 van 2004. Deze wetswijzigingen maakten het bijvoorbeeld illegaal om paspoorten van werknemers in beslag te nemen en maakten het makkelijker voor werknemers om van werkgever te veranderen. Volgens Wet nr. 21 van 2015, die is ingegaan in 2016, mochten arbeiders van werkgever veranderen nadat hun contract was afgelopen en met een 'verklaring van geen bezwaar' van de werkgever. ${ }^{9}$ De regering stelde een Loonbeschermingssysteem in dat de betaling van lonen aan arbeiders elektronisch volgde. ${ }^{10}$ In 2017 is een tijdelijk minimumloon van 750 riyal per maand - circa $€ 185$ - ingesteld. ${ }^{11}$ Sinds maart 2018 kunnen zogenoemde 'Commissies voor de beslechting van arbeidsconflicten' als snelrechtbanken in arbeidszaken zaken behandelen die door arbeidsmigranten worden aangebracht, waaronder een 'Workers Support and Insurance Fund', dat bedoeld is om aan arbeiders een vergoeding te betalen op grond van een besluit door deze Commissies. ${ }^{12}$

6. Human Rights Watch, How Can We Work Without Wages? (nr. 675), p. 57-62.

7. Amnesty International, Qatar: Migrant Workers in Labour Camps at Grave Risk amid COVID-19 Crisis, 2020, www.amnesty.org/en/latest/ news/2020/03/qatar-migrant-workers-in-labour-camps-at-grave-riskamid-covid19-crisis/.

8. Amnesty International, Qatar: Abuse of World Cup Workers Exposed, 2016, www.amnesty.nl/actueel/qatar-abuse-of-world-cup-workersexposed.

9. Amnesty International, 'New Name, Old System? Qatar's New Employment Law and Abuse of Migrant Workers, 2016, www.amnesty.org/ en/documents/mde22/5242/2016/en/

10. Maysa Zahra, Qatar's Legal Framework of Migration, 2018, www. gulfmigration.eu/media/pubs/exno/GLMM_EN_2016_01.pdf.pdf4.

11. Amnesty International, Reality Check: The State of Migrant Workers' Rights With Four Years To Go Until the Qatar 2022 World Cup, 2019, www.amnesty.org/en/documents/mde22/9758/2019/en/17.

12. Law No. 17 of 2018 related to the establishment of the Workers' Support and Insurance Fund, www.almeezan.qa/LawPage.aspx?id=7798\& language=ar; Qatar Council of Ministers, Law No. 13 of 2017 amending provisions of the Labour Law (No. 14 of 2004) en Civil and Commercial Procedures Code (Law No. 13 of 1990), www. almeezan.qa/LawPage.aspx?id=7310\&language $=$ ar.
Hoewel dit een aanzienlijke vooruitgang is, bestaan veel van deze wijzigingen nog slechts vooral op papier. ${ }^{13}$ Het kafala-systeem is nog diepgeworteld in de arbeidscultuur van het land en kan niet van de ene dag op de andere worden uitgeroeid. ${ }^{14} \mathrm{Zo}$ is het in beslag nemen van paspoorten nog steeds een wijdverbreide praktijk, die uiteindelijk het recht van werknemers op vrij verkeer schendt. ${ }^{15}$ Een recent onderzoek van Amnesty International heeft aan het licht gebracht dat de Arbeidscommissies niet efficiënt werken. Procedures zijn niet transparant en worden ernstig vertraagd. In geen van de 33 onderzochte gevallen ontvingen de arbeiders compensatie via het Commissie-systeem. In plaats daarvan kregen enkelen van hen delen van wat hun vorige werkgever hen schuldig was aangeboden als zij de zaak zouden laten vallen. ${ }^{16}$ Het verzekeringsfonds blijft niet gefinancierd en niet operationeel. ${ }^{17}$

Bovendien blijkt dat, als geprobeerd wordt om de juridische verantwoordelijkheid voor deze schendingen van rechten van arbeiders vast te stellen, het arbeidsrecht en de cultuur in Qatar niet de enige oorzaken van het probleem zijn. In feite zijn er veel verschillende actoren betrokken bij het ontwikkelen van de benodigde infrastructuur voor het WK in Qatar en andere grote sportevenementen die het land organiseert of in het verleden heeft georganiseerd, en daarom is het verdedigbaar dat ook zij betrokken zijn bij de mensenrechtenschendingen die arbeidsmigranten ondergaan. Deze diversiteit en veelvormigheid aan actoren makt de verantwoordelijkheid diffuser en doet de grenzen van de verantwoordingsplicht vervagen, aangezien er veel verschillende rechtsstelsels en contractuele kaders een rol spelen. Waarschijnlijk zal de schuld op anderen worden afgeschoven en zal er een beroep op vrijwaring worden gedaan. De gedupeerden of hun vertegenwoordigers hebben niet het noodzakelijke overzicht om te zien wie van de vele betrokken actoren verantwoordelijk gehouden kan worden voor welk forum, laat staan dat zij voldoende middelen en toegang hebben tot welk forum dan ook. Hierdoor is er maar weinig vooruitgang geboekt om de betrokken actoren ter verantwoording te roepen en om de gedupeerden te compenseren.

Tegen deze achtergrond analyseert dit artikel de verantwoordelijkheden op het gebied van mensenrechten van de verschillende actoren die betrokken zijn bij de bouwplaatsen van het WK in Qatar en bespreekt het de uitdagingen bij het ter verantwoording roepen van de verantwoordelijken. In het bijzonder maakt dit artikel een analyse van stakeholders om de verschillende betrokken actoren te onderscheiden (par. 1) en kijkt het vervolgens

13. Amnesty International, Reality Check: The State of Migrant Workers' Rights With Four Years To Go Until the Qatar 2022 World Cup, 2019, www.amnesty.org/en/documents/mde22/9758/2019/en/17.

14. Ibid. 5 .

15. Human Rights Watch, Significant Labor and Kafala Reforms, 2020, www.hrw.org/news/2020/09/24/qatar-significant-labor-and-kafalareforms.

16. Ibid.

17. Amnesty International, Reality Check: The State of Migrant Workers' Rights With Four Years To Go Until the Qatar 2022 World Cup, 2019, www.amnesty.org/en/documents/mde22/9758/2019/en/. 
naar het wettelijk kader waarbinnen dit evenement georganiseerd wordt, om de verschillende verantwoordelijkheden en mogelijke wegen naar verantwoordingsplicht daaruit te filteren (par. 2). Dit vereist een juridisch-pluralistische benadering, vanwege de diverse private en publieke regelgeving die van toepassing is. De omvang van dit artikel maakt een gedetailleerde beoordeling van elke optie onmogelijk, maar het is voldoende om de uitdagingen die bij elke optie horen uit te lichten. Om de hardnekkige uitdagingen te overwinnen wordt in paragraaf 3 een benadering van gedeelde verantwoordelijkheid geïntroduceerd voor het omgaan met mensenrechtenschendingen van arbeidsmigranten op de bouwplaatsen van het WK in Qatar.

\section{Wie kan eventueel verantwoordelijk worden gehouden?}

De belangrijkste uitdaging bij het aanpakken van deze zaken en het ter verantwoording roepen van de verantwoordelijke actoren is dat grote sportevenementen (mega-sporting events of MSE's), zoals het WK voetbal, gezamenlijk worden georganiseerd en uitgevoerd door een veelheid aan actoren, waardoor zeer complexe bestuursstructuren ontstaan die moeilijk afzonderlijk te herkennen zijn. Instanties die sportevenementen organiseren, zoals de Fédération Internationale de Football Association (FIFA), stellen de eisen waaraan die evenementen moeten voldoen. Gastlanden verbinden zich aan deze eisen en scheppen de onmisbare randvoorwaarden voor het aannemen van wetten, het geven van opdrachten en het verstrekken van vergunningen. Lokale organiserende commissies worden opgezet en verantwoordelijk gemaakt voor het opvolgen van de opdrachten en het inhuren van de noodzakelijke aannemers, die variëren van stadsplanners, architecten en logistiek experts tot bouwbedrijven, producenten van sportartikelen en andere evenement-gerelateerde merchandise, leveranciers van levensmiddelen, horecabedrijven en organisatoren van evenementen, inclusief hun eigen onderaannemers. ${ }^{18}$ Andere sleutelactoren zijn wervingsbureaus die de beschikbaarheid van arbeiders garanderen, nationale en internationale sponsorbedrijven, zoals McDonald's en Budweiser, en internationale mediabedrijven. ${ }^{19}$

Dit algemene overzicht van betrokken actoren is ook van toepassing op het WK in Qatar. Bij een poging te bepalen wie van deze actoren verantwoordelijk zou kunnen zijn voor de mensenrechtenschendingen die arbeidsmigranten ondergaan is het nodig om het misbruik te bekijken als een gevolg van een keten aan

18. Voor een uitgebreider overzicht van actoren, zie L. Amis, Mega-Sporting Events and Human Rights - A Time for More Teamwork? Business and Human Rights Journal, 2017 2(1), p. 135-141.

19. Fédération Internationale de Football Association, 2018 FIFA World Cup RussiaTM - FIFA Partners, 2017, www.fifa.com/worldcup/organisa tion/partners/index.html. handelingen en genomen besluiten. Een verslag van DLA Piper in opdracht van de regering van Qatar heeft drie zogenoemde 'verschillende domeinen van verantwoordelijkheid' geïdentificeerd: (i) de verantwoordelijkheid van de Staat Qatar (inclusief diens ministeries en raden), (ii) de verantwoordelijkheid van de regeringen van de staten van herkomst, en (iii) de verantwoordelijkheid van actoren die geen staten zijn. ${ }^{20}$ De regering van Qatar wordt vaak genoemd als de eerst verantwoordelijke actor in deze zaak, wat vanuit twee oogpunten juist is. ${ }^{21}$ Ten eerste is het Supreme Committee ('SC') een semi-overheidsorgaan dat toezicht houdt op de bouwplaatsen van het WK in Qatar, waaronder het inhuren van aannemers. ${ }^{22}$ Daarmee neemt de SC de verantwoordelijkheid op zich voor die bouwprojecten, waaronder de behandeling van de arbeiders. Ten tweede dragen het Qatarese Ministerie van Bestuurlijke Ontwikkeling, Arbeid en Sociale Zaken en de wetgevers de verantwoordelijkheid voor het wettelijk kader dat van toepassing is. Dit ministerie stelt de voor arbeid en de behandeling van arbeidsmigranten relevante wetten op en neemt die wetten aan, ${ }^{23}$ geeft aannemers en onderaannemers toestemming om nietQatarese arbeiders in te huren, ${ }^{24}$ en verstrekt vergunningen voor de werving van derden uit het buitenland. ${ }^{25}$ De overheden van landen van oorsprong van arbeidsmigranten, zoals Nepal, India, Bangladesh en alle andere landen van waaruit arbeidsmigranten komen, hebben invloed doordat zij in de positie zijn om wervingsbureaus die op hun grondgebied actief zijn te controleren. In een studie naar het falen van Nepal om arbeidsmigranten te beschermen hield Amnesty International Nepal verantwoordelijk voor het niet afdwingen van zijn eigen wetgeving op buitenlandse arbeid, het niet repatrieren van arbeiders die hulp nodig hadden, en het niet reageren op verzoeken van arbeiders om hulp. ${ }^{26}$

De niet-overheidsactoren die in aanmerking komen om verantwoordelijk te zijn voor de uitbuiting van arbeidsmigranten op WK-bouwplaatsen in Qatar zijn de aannemers en onderaannemers die arbeidsmigranten rechtstreeks inhuren, de wervingsbureaus die verantwoorde-

20. D.L.A. Piper, Migrant Labour in the Construction Sector in the State of Qatar, 2014, p. 25, www.dlapiper.com.

21. Zie bijvoorbeeld Sarath Ganji, Leveraging the World Cup: Mega Sporting Events, Human Rights Risk, and Worker Welfare Reform in Qatar, Journal on Migration and Human Security 2016, p. 221; Amnesty International, Qatar: Abuse of World Cup Workers Exposed, 2016, www.amnesty.org/en/press-releases/2016/03/abuse-of-world-cupworkers-exposed/.

22. Amnesty International, Reality Check: The State of Migrant Workers' Rights With Four Years To Go Until the Qatar 2022 World Cup, 2019, www.amnesty.org/en/documents/mde22/9758/2019/en/.

23. Migrant-Rights.org, Comparison of Migrant Workers Welfare Standards in Qatar, www.migrant-rights.org/activity_resource/17981/.

24. Qatar Legal Portal, Law No. 14 of 2004 on the Promulgation of Labour Law, Art. 23, www.almeezan.qa/LawPage.aspx?id=3961\&language $=$ en.

25. Ibid. art. 31.

26. Amnesty International, Turning People into Profits 2017, p. 39 e.v., p. 71 e.v., www.amnesty.org/download/Documents/ASA3162062017 ENGLISH.PDF. 
lijk zijn voor de levering van arbeidsmigranten en FIFA. ${ }^{27}$ De dertien officiële WK-bouwplaatsen worden geëxploiteerd door 38 hoofdaannemers en 306 onderaannemers. ${ }^{28}$ In de zaak van de Britse arbeider die overleed op een WK-bouwplaats was een Duits bedrijf de hoofdaannemer, terwijl de arbeider zelf in dienst was van een Zuid-Afrikaanse onderaannemer. ${ }^{29}$ Een studie van het European Centre for Constitutional and Human Rights onthulde dat aan een aantal transnationale bedrijven, bijvoorbeeld uit China, Zuid-Korea, Libanon, Saoedi-Arabië, Frankrijk, Oostenrijk of België, contracten zijn gegund voor de bouw van WK-infrastructuren. ${ }^{30}$ Het netwerk van SC-aannemers omvat niet alleen bedrijven die worden ingehuurd voor het bouwen van de stadions, maar ook bedrijven die materiaal en diensten verstrekken, zoals ICT-bedrijven en loodgieters- of lichtbedrijven, beveiligers, of landschapsarchitecten. $^{31}$

Ook al maakt het DLA Piper-rapport geen melding van FIFA, het is overduidelijk dat FIFA kan worden geschaard onder de mogelijk verantwoordelijke (nietoverheids)actoren vanwege haar invloed op de autoriteiten van Qatar op basis van het toezichthoudend kader van gastheerschap en de beslissing om het toernooi aan Qatar te gunnen. Als FIFA het bod van Qatar niet geaccepteerd had en het toernooi niet aan Qatar had gegund, zouden de aantallen arbeidsmigranten die nu in het land aanwezig zijn aanzienlijk lager zijn en zou daarmee ook de kans kleiner zijn dat dit misbruik zich voordoet. Uiteraard is ook dit een grond voor verantwoordelijkheid vergeleken met de betrokkenheid van de regering van Qatar of de private actoren die hierboven worden genoemd.

27. Aannemers en onderaannemers kunnen in dit kader gedefinieerd worden als: '[Elke] Een partij die een contractuele positie inneemt in de bevoorradingsketen van het SC. Hieronder vallen hoofdaannemers die een directe relatie met het SC hebben, evenals de bedrijven die een contractuele relatie met de hoofdaannemer hebben, ook wel genoemd de Tier I onderaannemer. Een aannemer van een Tier I aannemer wordt een Tier 2 onderaannemer genoemd.' Zie Impact, Annual External Compliance Report of the Supreme Committee for Delivery \& Legacy's Workers' Welfare Standards 2019, www.impacttlimited.com/wpcontent/uploads/2019/04/SC-Annual-Report-2019-Issue-2-digital. pdf3.

28. Ibid. 22.

29. Patrick Wintour, Qatar Agrees to Inquiry into Death of Briton at World Cup Stadium, The Guardian 2019, www.theguardian.com/uk-news/ 2019/jul/18/qatar-agrees-to-inquiry-into-death-of-briton-at-worldcup-stadium.

30. Linde Bryk \& Claudia Müller-Hoff, Accountability for Forced Labor in a Globalized Economy 2018, www.ecchr.eu/fileadmin/Publikationen/ ECCHR_QATAR.pdf11.

31. Supreme Committee for Delivery \& Legacy, Business Opportunities Related to the 2022 FIFA World Cup Qatar, https://sc.qa/sites/default/ files/docs/Qatar-2022-business-opportunities-EN.PDF.

\section{Hoe kunnen de verschillende stakeholders verantwoordelijk worden gehouden?}

Om iemand in rechte verantwoordelijk te houden, moet de betreffende actor een wettelijke verplichting hebben geschonden. In dit geval hebben wij het over verplichtingen op grond van mensenrechten en arbeidsrecht, die zowel op internationaal als nationaal niveau bestaan. Terwijl private partijen in het algemeen gebonden zijn aan de wetten van hun thuislanden en zich moeten houden aan nationale wetten in het land waar zij actief zijn, hebben overheidsactoren verplichtingen op grond van internationale mensenrechten in de vorm van internationale verdragen waarmee zij hebben ingestemd, zoals het Internationaal Verdrag inzake burgerrechten en politieke rechten (ICCPR), of het Internationaal Verdrag inzake economische, sociale en culturele rechten (ICESCR). Dwangarbeid is uitdrukkelijk verboden volgens artikel 8 van het ICCPR en twee van de fundamentele IAO-Conventies over dwangarbeid (C-029 en C-105). Verwante rechten, zoals het recht van eenieder om een vakbond op te richten en daar lid van te worden, als vervat in artikel 8 van het ICESCR, staan ook op het spel. In 2018 heeft Qatar het ICCPR en het ICESCR geratificeerd, maar wel met een voorbehoud voor wat betreft artikel 8 ICESCR. ${ }^{32}$ Ondanks deze beperking is de regering van Qatar in het algemeen verplicht om verschillende mensenrechten, waaronder arbeidsrechten, te respecteren, te beschermen en uit te voeren en om schendingen door derden te voorkomen en te beperken en om schendingen die zich voorgedaan hebben op te lossen volgens artikel 2 van het ICCPR. ${ }^{33}$ Dit is ook van toepassing op regeringen van uitzendende landen die het ICCPR geratificeerd hebben. Deze landen zijn verplicht om arbeidersrechten te beschermen tegen corrupte en uitbuitende praktijken door wervingsbureaus die binnen hun rechtsgebied actief zijn en zij moeten ervoor zorgen dat als deze bureaus de wet niet naleven, en arbeiders niet werven op een wijze die in overeenstemming is met de mensenrechten, daartegen kan worden opgetreden en ook wordt opgetreden.

Het afdwingen van deze verplichtingen op internationaal niveau is mogelijk via het systeem van verantwoording van de $\mathrm{VN}$-verdragsorganisaties, waaronder het Mensenrechtencomité, of het Comité voor economische, sociale en culturele rechten, evenals het klachten-

32. De regering van Qatar heeft officieel deze 'verklaring' afgelegd: 'De Staat Qatar zal dat wat bedoeld wordt met "vakbonden" en hun verwante aangelegenheden als bepaald in artikel 8 van het Internationaal verdrag over economische, sociale en culturele recht[en] zodanig interpreteren dat dit in overeenstemming is met de bepalingen van Arbeidswet en nationale wetgeving. De Staat Qatar behoudt zich het recht voor om dat artikel toe te passen in overeenstemming met dat begrip.' See OHCHR, Status of Ratification - Interactive Dashboard 2019, http://indicators.ohchr.org/.

33. International Covenant on Civil and Political Rights art 2 (3)(a). 
mechanisme van de IAO (Internationale Arbeidsorganisatie). De laatstgenoemde is in 2014 nog gebruikt toen een aantal lidstaten van de IAO een klacht indienden tegen Qatar wegens het schenden van haar verplichtingen onder IAO Conventies C029 en C081. ${ }^{34}$ De grondslag van de klacht was de sponsorwet van Qatar en het gebrek aan initiatief om veelvoorkomende onwettige praktijken te stoppen, zoals het innemen van paspoorten, het vervangen van contracten en het opleggen van wervingskosten. Deze klacht was voor de IAO aanleiding om een kantoor in Qatar te openen en bracht uiteindelijk arbeidshervormingen teweeg. Er is geen sprake van dat de mechanismes van de verdragsorganisaties voor mensenrechten ook gelden, want Qatar heeft de betreffende Optional Protocols niet geratificeerd. ${ }^{35}$ De speciale procedures die bij de VN Mensenrechtenraad beschikbaar zijn, waaronder de klachtenprocedure, zijn alternatieve opties om gevallen van dwangarbeid aan te pakken waarmee de arbeidsmigranten van het WK in Qatar geconfronteerd worden. ${ }^{36}$ Echter, net als bij de procedures van de verdragsorganisaties, kunnen deze routes alleen worden gevolgd als alle nationale rechtsmiddelen zijn uitgeput, wat voor arbeidsmigranten moeilijk te realiseren is. Hun toegang tot het rechtssysteem in Qatar is praktisch geblokkeerd, hun mogelijkheden om zich te organiseren zijn beperkt en het recht om lid te worden van een vakbond is in Qatar niet zover ontwikkeld als in andere landen. ${ }^{37}$

Nationale rechtsstelsels omvatten tot op zekere hoogte wetten die een negatieve verplichting opleggen aan nietoverheidsactoren, zoals bedrijven, om mensenrechten te respecteren en die het slachtoffers mogelijk maken om civiele vorderingen in te stellen in gevallen waarin deze verplichting is geschonden. ${ }^{38}$ Afhankelijk van het land kunnen de wetten en verboden echter verschillen en elk land heeft zijn eigen (mensenrechten)problemen die vorm geven aan bestaande wetgeving en verplichtingen. ${ }^{39}$ Bovendien is het probleem dat MSE's steeds vaker plaatsvinden in landen met een minimaal of ontoereikend niveau van mensenrechten binnen hun binnenlandse rechtsstelsels. Verder kunnen sommige wetten meer rechtstreeks van toepassing zijn op één private aannemer en minder rechtstreeks op een onderaannemer, bijvoorbeeld, of verschil maken in de wijze waarop die wetten van toepassing zijn op bedrijven in

34. ILO Governing Body, Complaint Concerning Non-Observance by Qatar of the Forced Labour Convention, 1930 (No. 29), and the Labour Inspection Convention, 1947 (No. 81), Made by Delegates to the 103rd Session (2014) of the International Labour Conference under Article 26 (2016) Appendix 1, www.ilo.org/wcmsp5/groups/public/---ed_norm/ ---relconf/documents/meetingdocument/wcms_459148.pdf.

35. OHCHR, 'Status of Ratification - Interactive Dashboard' 2019, http:// indicators.ohchr.org/.

36. UN General Assembly Resolution adopted by the General Assembly on 15 March 2006, A/RES/60/251, par. 6.

37. OHCHR, Status of Ratification - Interactive Dashboard 2019, http:// indicators.ohchr.org/.

38. Olivier De Schutter, Corporations and Economic, Social, and Cultural Rights, in: Economic, Social, and Cultural Rights in International Law, Oxford University Press 2014, p. 199

39. Andrew Clapham, Human Rights Obligations of Non-State Actors, Oxford University Press 2006, p. 437-439. tegenstelling tot verenigingen, zoals FIFA. Naast binnenlandse wetten spelen ook internationale richtlijnen een rol, zoals de VN-richtsnoeren voor het bedrijfsleven en de mensenrechten, of Richtlijnen voor multinationale ondernemingen van de OESO (Organisatie voor Economische Samenwerking en Ontwikkeling). Zij zijn niet wettelijk bindend voor niet-overheidsactoren, maar scheppen niettemin een standaard voor verwacht gedrag en hun toepassing op de sportwereld meer in het algemeen is bevestigd door FIFA zelf en andere stakeholders. ${ }^{40}$

Terwijl een studie van Amnesty International uitwijst dat wervers en werkgevers volgens de wet van Qatar civiele en strafrechtelijke boetes riskeren, waaronder gevangenisstraffen tot maximaal vijftien jaar wegens medeplichtigheid aan dwangarbeid en mensenhandel, zijn in werkelijkheid de manieren om de verschillende private actoren verantwoordelijk te houden beperkt. ${ }^{41}$ Het arbeidsrecht van Qatar bevat een aantal bepalingen die van toepassing zijn op werkgevers en wervers. In de Arbeidswet van Qatar is echter geen algemene bepaling op gelijke en humane behandeling te vinden en de aansprakelijkheid van werkgevers en wervers in geval van niet-nakoming van de wet is beperkt. ${ }^{42}$ Wervers kunnen aansprakelijk worden gesteld voor het schenden van de wet door het berekenen van wervingskosten, maar eventuele verantwoordelijkheden van wervers houden op te bestaan zodra de arbeider is afgeleverd aan zijn werkgever. ${ }^{43} \mathrm{Na}$ recente wetswijzigingen kunnen werkgevers worden beboet en een gevangenisstraf krijgen als zij betaling inhouden. ${ }^{44}$ Daartegenover kunnen werkgevers niet verantwoordelijk worden gehouden voor het niet nemen van voldoende arbomaatregelen, noch voor het niet respecteren van het recht van arbeiders op behandeling en het ontvangen van een vergoeding bij een bedrijfsongeval. ${ }^{45}$

Het recht inzake onrechtmatige daad is een ander middel dat kan worden aangewend als het strafrecht of het civiele recht niet voldoende bescherming bieden. Het kan in het bijzonder nuttig zijn om dochterondernemingen van buitenlandse ondernemingen die actief zijn in Qatar verantwoordelijk te houden in hun land van

40. Institute for Human Rights and Business - Mega Sporting Events, White Paper 1.2 Sports Governing Bodies and Human Rights Due Diligence 2017, geraadpleegd op 6 februari 2017, www.ihrb.org/focus-areas/ mega-sporting-events/white-paper-1.2-sports-governing-bodies; Fédération Internationale de Football Association, FIFA's Human Rights Policy 2017, http://resources.fifa.com/mm/document/affederation/ footballgovernance/02/89/33/12/fifashumanrightspolicy_neutral.pdf, geraadpleegd op 11 juni 2017; IOC, Host City Contract Principles Games of the XXXIII Olympiad in 2024, 2017, https://stillmed. olympic.org/Documents/Host_city_elections/Host_City_Contract_ Principles.pdf.

41. Amnesty International, The Dark Side of Migration: Spotlight on Qatar's Construction Sector Ahead of the World Cup 2013, p. 112, www. amnesty.org/download/Documents/16000/mde220102013en.pdf, geraadpleegd op 24 mei 2019.

42. Migrant-Rights.org, Comparison of Migrant Workers Welfare Standards in Qatar, www.migrant-rights.org/activity_resource/17981/14.

43. Qatar Legal Portal, Law No. 14 of 2004 on the Promulgation of Labour Law (nr. 711) art. 34, 145

44. Ibid. art. 145bis.

45. Ibid. art. 109 en art. 110. 
vestiging. Zo zou een arbeidsmigrant uit India de buitenlandse partner van de Qatarese werkgever voor de rechter kunnen brengen van het woonland van die partner. De wettelijke basis voor deze zaken van aansprakelijkheid voor onrechtmatige daad is gewoonlijk de zorgplicht van bedrijven. ${ }^{46}$ De wettelijke normen binnen het recht inzake onrechtmatige daad verschillen echter per rechtsgebied en het is onduidelijk in hoeverre vonnissen die in het ene rechtsgebied worden gewezen in het andere rechtsgebied ten uitvoer kunnen worden gelegd. Kortom, het is niet verrassend dat pogingen om juridische verantwoordelijkheid te bepalen voor de onderhavige gevallen niet slaagden of nog niet beslist zijn. In een recente zaak voor het Handelsgericht Zürich beschuldigde een coalitie van nationale en internationale vakbonden, samen met een arbeidsmigrant uit Qatar, FIFA ervan verantwoordelijk te zijn voor de schending van internationale mensenrechten en arbeidsrechten door het WK voetbal 2022 aan Qatar toe te kennen. Deze rechter deed de zaak vrij snel af door te stellen dat de aantijgingen niet nauwkeurig genoeg waren om tot een finaal vonnis te komen dat ten uitvoer kon worden gelegd. Tevens stelde deze rechter dat hij niet het bevoegde forum was om de gestelde schendingen van mensenrechten te behandelen. ${ }^{47}$ In 2015 diende de ngo Sherpa een klacht in bij het Openbaar Ministerie in Nanterre, Frankrijk, tegen het Franse bedrijf Vinci Construction Grands Projets dat betrokken is bij infrastructuurprojecten voor het openbaar vervoersysteem in Qatar en beschuldigde dit bedrijf ervan betrokken te zijn bij dwangarbeid, slavernij en verzwijging. ${ }^{48}$ Het $\mathrm{OM}$ begon een onderzoek, maar sloot het voorlopig onderzoek af in januari 2018. In november 2018 bracht de ngo een nieuwe zaak aan, deze keer een civielrechtelijke vordering tot schadevergoeding, samen met het Comité contre l'Esclavage Moderne en zes voormalige Indiase en Nepalese arbeiders. Zij klaagden Vinci, Vinci Construction Grands Projets (VCGP), haar Qatarese dochteronderneming Qatari Diar Vinci Construction (QDVC), en hun bestuurders en managers aan voor dwangarbeid en schuldarbeid, mensensmokkel, werk dat onverenigbaar is met de menselijke waardigheid, nalaten om eerste hulp te verlenen, bewust in gevaar brengen van mensenlevens, en het verzwijgen van met deze misdrijven behaalde winsten. ${ }^{49}$ Dit onderzoek is begonnen in november 2019 en lijkt nog steeds gaande te zijn. ${ }^{50}$

46. Linde Bryk \& Claudia Müller-Hoff, Accountability for Forced Labor in a Globalized Economy 2018, www.ecchr.eu/fileadmin/Publikationen/ ECCHR_QATAR.pdf20.

47. FNV, Bangladeshi Free Trade Union Congress, BWI \& Nadim Shariful Alam v FIFA, Handelsgericht Kanton Zürich (3 January 2017).

48. Sherpa, Legal Action against Vinci in Qatar: Vinci Institutes Defamation Proceedings, Claiming Exorbitant Damages from Sherpa Organisation and Its Employees 2015, www. asso-sherpa.org/legal-action-vinci-qatarvinci-institutes-defamation-proceedings-claiming-exorbitant-damages-

49. Ibid. sherpa-organisation-employees, geraadpleegd op 5 maart 2018.

50. L'Express, Mondial-2022: un juge enquête sur des accusations de 'travail forcé' visant Vinci 2020, www.lexpress.fr/actualite/societe/justice/ mondial-2022-un-juge-enquete-sur-des-accusations-de-travail-forcevisant-vinci_2119363.html.

\section{Het veranderen van de spelregels richting gedeelde verantwoordelijkheid}

De tekortkomingen van bestaande wettenstelsels roepen om een herziene aanpak van gevallen van mensenrechtenschendingen die ontstaan uit maatregelen genomen door vele diverse actoren in het kader van MSE's, zoals het WK voetbal. Een manier om de benadering te herzien is door meer op het feit te focussen dat een veelheid en diversiteit aan actoren betrokken is en dat elk van hen een rol kan spelen in het veroorzaken van schade aan mensenrechten in verband met MSE's. Een concept dat bij die benadering zou passen is het concept van gedeelde verantwoordelijkheid. ${ }^{51}$ Het is hierbij vooral de bedoeling dat verantwoordelijkheid wordt gedeeld tussen een veelheid aan actoren die allen hebben bijgedragen an een schadelijke uitkomst en dat de juridische verantwoordelijkheid tussen meer dan één van de daaraan bijdragende actoren verdeeld wordt. ${ }^{52}$ Toegepast op arbeidsmigranten in Qatar zou dit kunnen betekenen dat de Qatarese regering, de SC en het organiserend comité, het betrokken bouwbedrijf of bedrijven in geval van joint ventures, het betrokken wervingsbureau en FIFA de juridische verantwoordelijkheid zouden delen voor de mensenrechtenschendingen die de arbeiders hebben ondergaan, voor zover elk van hen aan de schade heeft bijgedragen.

Uiteraard is dit een eenvoudige voorstelling van zaken en zullen er nog talloze uitdagingen op ons pad komen wanneer wij proberen om tot een dergelijke benadering te komen. Een van de grootste problemen van gerechtelijke mechanismen is dat ze traditioneel gebaseerd zijn op individuele en exclusieve verantwoordelijkheid. Zaken waarbij meerdere boosdoeners betrokken zijn die verantwoordelijkheid delen, dagen rechtbanken en andere mechanismen voor geschillenbeslechting uit om op inhoudelijk en procedureel niveau regels te vinden voor het toerekenen en toedelen van verschillende delen van verantwoordelijkheid. De verschillende actoren dragen op verschillende manieren bij en het is een belangrijke uitdaging om na te gaan op welk punt een bijdrage relevant is voor de mate waarin een actor verantwoordelijkheid draagt.

Maar nu het goede nieuws: een gedeelde verantwoordelijkheid-benadering van MSE-gerelateerde mensenrechtenschendingen kan een veelheid aan vormen aannemen, variërend van gerechtelijke en buitengerechtelijke mechanismen voor het bepalen van verantwoorde-

51. Dit standpunt is ook elders ingenomen, zie D. Heerdt, Blurred Lines of Responsibility and Accountability - Human Rights Abuses at MegaSporting Events, Intersentia 2021, of D. Heerdt, Winning at the World Cup: A matter of protecting human rights and sharing responsibilities, Netherlands Quarterly of Human Rights 2018 36(2), p. 86-92. Over het begrip 'gedeelde verantwoordelijkheid', zie André Nollkaemper \& Dov Jacobs, Shared Responsibility in International Law: A Conceptual Framework, Michigan Journal of International Law 2013, p. 34.

52. André Nollkaemper e.a., The Practice of Shared Responsibility in International Law, Cambridge University Press 2017, p. 3. 
lijkheid en verantwoordingsplicht tot transnationale en internationale regulering. Met andere woorden: een benadering van gedeelde verantwoordelijkheid kan worden toegepast en onderzocht op een ex ante en ex post wijze. Niet alleen kan dit helpen om de obstakels te overwinnen die slachtoffers tegenkomen door de actoren die verantwoordelijk zijn voor de schade die zij hebben geleden afzonderlijk eruit te pikken, maar door verantwoordelijkheden te verduidelijken binnen het multistakeholder netwerk en precedenten te scheppen kan het ook bijdragen aan het voorkomen van meer schendingen bij toekomstige evenementen. Terwijl bij pogingen tot het bepalen van aansprakelijkheid voor schendingen die gebeurd zijn om de getroffenen te compenseren gedeelde verantwoordelijkheid onderzocht zou kunnen worden op ex post wijze, kunnen wijzigingen in regelgeving en beleid die relevant zijn voor de organisatie en voor het organiseren van die evenementen helpen om gedeelde verantwoordelijkheid op een ex ante wijze toe te passen. In feite kunnen bepaalde sporen van een gedeelde verantwoordelijkheid-benadering of -begrip worden herkend in recente pogingen om mensenrechtenproblemen aan te pakken die door het organiseren van MSE's aan de oppervlakte komen. In 2017 hebben FIFA en andere sportorganisaties nieuwe regels voor bieden en als gastheer optreden aangenomen, waaronder contractuele verplichtingen met betrekking tot mensenrechten die bindend zijn voor een aantal van de verschillende actoren die betrokken zijn, in het bijzonder de gastheerautoriteiten, het Organisatiecomité, de betreffende nationale sportorganisaties en mogelijke andere actoren die uitdrukkelijk worden genoemd. ${ }^{53}$ Dit kan geinterpreteerd worden als gedeelde verantwoordelijkheid op een ex ante wijze, maar met ex post implicaties in geval de regelgeving en contractuele verplichtingen worden geschonden. Deze nieuwe regels zijn voor het eerst toegepast bij de toekenning van het WK van 2026, wat inhield dat de bieders een risico-evaluatie voor mensenrechten moesten maken, een mensenrechtenstrategie moesten presenteren, en garanties voor mensenrechten van betreffende overheden moesten overleggen bij de biedingsdocumenten. Zodoende werden deze documenten ook meegenomen bij de beoordeling van de verschillende biedingen. Toen FIFA in 2019 overwoog om het aantal deelnemende teams aan het WK 2022 uit te breiden, wat betekend zou hebben dat Qatar te klein zou zijn om als gastheer op te treden en SaoediArabië en Oman als mogelijke co-gastheren werden overwogen, speelden de net aangenomen mensenrechtencriteria geen rol. Uiteindelijk heeft FIFA deze plannen laten vallen. ${ }^{54}$

Meer in het algemeen ziet het ernaar uit dat veel stakeholders in de MSE-branche en de sportwereld zich steeds meer bewust worden van hun mogelijk aandeel in

53. Daniela Heerdt, Tapping the potential of human rights provisions in mega-sporting events' bidding and hosting agreements, Int Sports Law J 2018, 17, p. $170-185$

54. Tariq Panja, FIFA Drops Plan for 48-Team World Cup in 2022, The New York Times 2019, www.nytimes.com/2019/05/22/sports/fifa-2022world-cup-48-teams.html. verantwoordelijkheid. Dit is ook te zien aan de maatregelen die volgden op de publicatie van het artikel in The Guardian in februari 2021. Nationale voetbalbonden, nationale voetbalteams en zelfs individuele spelers gebruikten het begin van de kwalificatiewedstrijden voor het WK in 2022 om zich uit te spreken tegen de uitbuiting van arbeidsmigranten in Qatar. Hierdoor werden oproepen om het evenement te boycotten luider, maar de meeste mensenrechtenorganisaties en vakbonden namen snel afstand van die oproepen met als reden dat het boycotten van het evenement de arbeiders in Qatar niet zou helpen en elke vooruitgang die in de regio geboekt is zou kunnen ondermijnen. Hoewel deze maatregelen niet als gevolg van juridische verantwoordelijkheid genomen zijn, laten ze niettemin zien dat die actoren ook de invloed hebben om op te roepen tot verandering. Bovendien moeten zij zich, in het geval van nationale voetbalbonden, als leden van FIFA houden aan het reglement van FIFA, dat een verplichting op mensenrechtengebied bevat. Het opvolgen van deze verplichting voor leden kan betekenen dat er meer gedaan wordt dan alleen bewustheid laten zien en zaken aan de kaak stellen, en dat FIFA ter verantwoording kan worden geroepen voor haar verplichting op mensenrechtengebied in de toekomst en dat zij deze verplichtingen op een nationaal niveau weerspiegelt. De Duitse voetbalbond - Deutscher Fussball-Bund - heeft al een eerste stap in die richting gezet. ${ }^{55}$

\section{Conclusie}

Het duurt nog maanden voordat het WK voetbal in Qatar begint; dat biedt kansen om de situatie van arbeidsmigranten ten goede te blijven veranderen. De duurzaamheid van verbeteringen, zowel intern als extern, is van het grootste belang. Aan de ene kant vormen de mensenrechtenproblemen in verband met het WK in Qatar een belangrijke casestudy waarvan toekomstige gastheren kunnen leren. Niet alleen studies die door ngo's worden gedaan, of berichten in de media, maar ook academische studies en bijdragen als deze kunnen helpen om bewijs te verzamelen en een schat aan literatuur te creëren waarin goede en kwade praktijken worden gedeeld. Sportorganisaties en internationale organisaties zouden de uitwisseling van kennis tussen verschillende gastheren moeten bevorderen, op basis van het beschikbare materiaal. Aan de andere kant dient de vooruitgang die in Qatar geboekt is ook na het WK te worden voortgezet en niet te worden vergeten wanneer de finale in het WK gespeeld is en de winnaar gelauwerd is. De grootste angst van de civil society is dat zodra de aandacht voor Qatar verslapt, de positieve wijzigingen en erfenis niet blijvend zullen zijn. Om dit te voorkomen en ervoor te zorgen dat positieve ontwikkelingen langdurig zijn, is samenwerking tussen de verschillende betrokken actoren van het grootste belang,

55. DFB 2020, www.dfb.de/menschenrechte/menschenrechte-beim-dfb/. 
op basis van 'collaborative sport governance' en benaderingen van gedeelde verantwoordelijkheid. ${ }^{56}$ Het aanpakken van MSE-gerelateerde uitdagingen op mensenrechtengebied gaat duidelijk verder dan de capaciteit van de afzonderlijke betrokken actoren. ${ }^{57}$

56. H.E. Meier \& B. Garcia, Beyond sports autonomy: a case for collaborative sport governance approaches, Int J of Sport Policy and Politics 2021, p. 13.

57. L. Amis, Mega-Sporting Events and Human Rights - A Time for More Teamwork?, Business and Human Rights Journal 2017, 2(1), p. 135-141. 